\title{
Impact of Manufacturer Brand Innovation on Retailer Brands
}

\author{
Ranga Chimhundu (Corresponding author) \\ School of Management and Marketing, Faculty of Business, University of Southern Queensland \\ Toowoomba, QLD 4350, Australia \\ Tel: 61-7-4687-5759Ｅ-mail: Ranga.Chimhundu@usq.edu.au \\ Robert P. Hamlin \\ Department of Marketing, School of Business, University of Otago \\ PO Box 56, Dunedin 9054, New Zealand \\ Tel: 64-3-479-8161Ｅ-mail: rob.hamlin@otago.ac.nz \\ Lisa McNeill \\ Department of Marketing, School of Business, University of Otago \\ PO Box 56, Dunedin 9054, New Zealand \\ Tel: 64-3-479-5758 E-mail: lisa.mcneill@otago.ac.nz
}

\begin{abstract}
The article explores the impact of manufacturer brand innovation on retailer brands in grocery product categories, drawing on literature from category management, power and product innovation. It is argued that the consumer packaged goods literature has largely portrayed manufacturer brand innovation in relation to retailer brands as a competitive tool that is employed against the retailer brands. The alternative view of manufacturer brand innovation as an enhancer of retailer brands has not been fully addressed academically. The article further argues that aspects of manufacturer brand innovation that enhance retailer brands have relevance for the determination of strategic policies that govern the coexistence of the two types of brands in supermarket categories. The paper offers a fresh perspective in explaining the coexistence of manufacturer brands and retailer brands in grocery retail categories. Aspects of manufacturer brand innovation that positively impact on the welfare of retailer brands play a strategic role.
\end{abstract}

Keywords: Manufacturer brand, Retailer brand, Product innovation, Grocery retailing, Product Category, Power, Dependency

\section{Introduction}

The dominance of manufacturer brands (national brands) in grocery product categories is increasingly being challenged by retailer brands (store brands or private label). This state of affairs is more pronounced in some categories than others. By definition, manufacturer brands are brands owned by manufacturers and retailer brands are those owned by retailers (Baden-Fuller, 1984). The two types of brands are placed side-by-side at point of sale in grocery retail outlets. The brands feature in categories, which in simple terms are groups of similar products; for instance, milk category, tomato sauce category, and so on. The increasing change in the product composition of supermarket categories in this regard merits a close examination of the coexistence of the two types of participating brands. This article sets out to determine the impact of manufacturer brand innovation on retailer brands in supermarket categories. The objectives of the article are; firstly, to identify aspects of manufacturer brand innovation that might inhibit and/or enhance retailer brands in grocery product categories; and secondly, to assess how relevant aspects of manufacturer brand innovation that enhance retailer brands are for the determination of strategic management regimes that govern the coexistence of the two types of brands in the categories.

The term 'brand innovation' here is used to capture all innovative activities ranging from incremental to radical; thus the entire continuum from minor product or packaging changes to the introduction of totally new products/brands is taken into account, as well as the marketing activities associated with the innovations. The article explores three literature themes; category management, power/dependency and brand/product innovation, and employs a qualitative empirical study to argue that the role of manufacturer brand innovation in driving and 
growing grocery packaged goods categories and benefiting retailer brands in the process has escaped the level of academic attention it deserves, and therefore needs to be well-articulated. It is also argued that the determination of strategic management regimes that govern the coexistence of manufacturer brands and retailer brands is partly influenced by manufacturer brands' ability to enhance retailer brands in the categories. The research aims to create a better understanding of the strategic coexistence of manufacturer brands and retailer brands in grocery categories.

\section{The Management of grocery packaged goods categories}

Retail chains are largely making use of a management technique called category management to manage supermarket product categories. Category management entails a joint, manufacturer (supplier)/ retailer process of defining and managing product categories as strategic business units (Desrochers et al., 2003; Joint Industry Project, 1995; Kracklauer et al., 2004; Nielsen, 1992), and is characterised by the sharing of information and technology resources between manufacturers and retailers. Cooperation and collaboration are key elements in the process of leveraging skills and resources between the two parties (Freedman et al., 1997) as they perform valuable complementary roles.

Whereas category management represents strategic management by category, brand management represents strategic management by brand (Nielsen, 1992). There is a close relationship between category management and brand management in that supermarket product categories are actually driven by brands, and the stronger the brand the better in the sense that strong brands pull customers to the category. Therefore, while category management is applied in dealing with supermarket categories, brand management is still important. It is from this perspective that this paper takes an interest in the brand/product innovation activities of manufacturer brands and retailer brands as more innovative brands are more likely play a greater role in the categories than the less innovative ones.

Despite the level of manufacturer and retailer cooperation with respect to category management, supermarket product categories are inherently characterised by intense competition among participating brands, including competition between manufacturer brands and retailer brands. In relation to the manufacturer brand, the retailer brand is seen as benefiting from the special status of the retailer being both customer and competitor (Hoch and Banerji, 1993), as well as owner of point of sale. Furthermore, there has been a rise in the power of the trade due to retail consolidation and concentration, the growth of retailer brands and retailer ready access to information as a result of the increased utilisation of information technology (Chimhundu and Hamlin, 2007; Rubio and Yague, 2008; Sullivan and Adcock, 2002; Weitz and Wang, 2004). The possible unique relationship between manufacturer brands and retailer brands, of being in a state of competition and cooperation at the same time, prompts the examination of a number of relevant variables that characterise the coexistence of the two types of brands in the categories.

In the coexistence of manufacturer brands and retailer brands, the category management and retailer brand literatures offer a number of strategic policy decision areas that include retailer brand growth and share targets (Coriolis Research, 2005; Sethuraman, 2006), merchandising, and category rationalisation (Lindblom, 2001; Nielsen, 1992). This study makes the reasonable assumption that power and dependency relationships between manufacturers and retailers would logically have an influence on power and dependency relationships between brands owned by manufacturers (manufacturer brands) and those owned by retailers (retailer brands) in the categories, and that product innovation is a key activity area that has the potential to affect these relationships. The role of manufacturer brand and retailer brand innovation in the categories in shaping the strategic policy decision areas can therefore be better understood in a study that employs the theories of power and dependency.

\section{Power and dependency}

Power is the influence or control that a group, organisation or individual exerts upon the decisions, attitudes and behaviours of other groups, organisations or individuals (Hunt and Nevin, 1974). Power has been conceptualised from various perspectives that include bases of power (French and Raven, 1959) and power-dependence relationship (Emerson, 1962; Hickson et al., 1971; Mintzberg, 1983; Pfeffer, 1981). This article takes the view that the conceptualization of power should not be limited to people and organisations, but to other phenomenon as well. Therefore, the bases of power that are presented next in this section, are equally applicable to humans, organizations and other phenomenon such as brands.

\subsection{Bases of power}

French and Raven (1959) identified five bases of power as reward, coercive, legitimate, referent and expert power. Reward power is based on the ability to mediate rewards or to remove negative outcomes. Coercive 
power is a type of power that is based on the ability to punish the other member for not complying. Legitimate power is based on the belief that one party has the right to prescribe behaviour. Referent power has its basis in one party's desire to identify with the other (French and Raven, 1959). The party that desires to associate with the other party automatically puts the latter in a position of power. Expert power is based on the belief by one party that the other party has special knowledge or expertise in a given area (Cartwright, 1965). The total power of a firm is a combination of several power bases. Positive and negative synergistic effects can result from the combination of these power bases (Stern and El-Ansary, 1977); therefore there are interlinkages among the various sources of power. With respect to the product innovation activities of manufacturer brands and retailer brands in grocery retail categories, aspects related to reward, coercive, legitimate, referent and expert power are deemed to be relevant in assessing the nature and magnitude of interdependence and the possible positive and/or negative impact of one type of brand's activities on the other.

\subsection{Power-dependence relationship}

The concept of dependence is largely central in most discussions of power (Diamantopoulus, 1987). Dependency theory argues that the power to influence or control resides in the extent to which one party depends on the other for the things that s/he values (Emerson, 1962; Hickson et al., 1971; Pfeffer, 1981). The dependence can manifest itself in economic, social or other terms. A balanced power relationship is an equilibrium situation in which both parties have equal amounts of power (Wilkinson, 1973). An asymmetrical power relationship exists where there is disparity in power between the relevant parties (Diamantopoulus, 1987). The party over which the power is held can also have countervailing power, which is the ability to counter the power of the other party so that it is not used or is neutralised (Hunt and Neville, 1974). While power and dependency have been used in studies of manufacturer and retailer relationships (e.g. Dapiran and Hogarth-Scott, 2003), the theories have not been employed to specifically focus on the relationships between manufacturer brands and retailer brands, especially in the changing grocery retail landscape characterised by high retail consolidation and concentration, and where retailer brands are gaining more momentum. In the product innovation activities of manufacturer brands and retailer brands in grocery categories, it is envisaged that there is a power - dependence relationship whose nature still has to be better understood through empirical research.

\section{Manufacturer and retailer brand innovation in grocery packaged goods categories}

The importance of innovation in general as a driving force for the growth of companies is well-documented in the literature (e.g. BCG, 2005; Brenner, 1994; Doyle and Bridgewater, 1998; Hardaker, 1998). Engaging in constant innovation also enables offerings to retain a strong market presence (Johne, 1999; Keller, 2003). Manufacturer and retailer brands engage in some level of innovation ranging from incremental changes to radical product innovation. The consumer packaged goods literature however, has largely portrayed manufacturer brand innovation in relation to retailer brands as a competitive tool that is employed against the retailer brands, in addition to competing with other manufacturer brands. Verhoef et al. (2000) noted that superior brand innovation is a successful strategy in competing with retailer brands. Kumar and Steenkamp (2007, p. 51) established from their study of "scores of categories in over 20 countries across the world, [that] private label success is 56 percent higher in categories with low innovation compared to categories with high innovation". Other research has similarly found that retailer brands are more successful in categories experiencing low innovation by manufacturers (Coriolis Research, 2002), and that FMCG manufacturers have managed to grab share in traditional strongholds of retailer brands through innovation (Information Resources Inc., 2005). The literature therefore largely suggests that manufacturer brand innovation does have a negative impact on retailer brands in FMCG categories. The alternative view of manufacturer brand innovation having a positive impact on retailer brands has not been investigated in depth. The inherent interdependence between manufacturer and retailer brands in the category management set-up justifies a case for investigating manufacturer brand innovation as an enhancer of retailer brands in the categories.

In addition, experts hold different views on the state of the contributions to innovation by retailer and manufacturer brands (Conn, 2005). One view is that retailer brands have become masters of their own destinies on innovation (Conn, 2005) and can do a lot on their own without having to deal with manufacturers. However, historically, retailers have largely been followers of manufacturer brands on innovation (Hoch and Banerji, 1993); so this view may be an indicator of a new development that applies to all or some grocery retail industries. The other view is that manufacturer brands are leading the way and setting the standard on innovation as research has shown that companies that are more experienced in product innovation tend to have greater capacity to develop novel and complex products than those that are less experienced (Alegre et al., 2005). Manufacturers are generally considered to be more experienced than retailers in this regard. And additionally, retailer brand development is considered as not being backed by enough research and development money to generate 
break-through new products (Conn, 2005). An assessment of the two points of view is also worth exploring in the coexistence relationship of manufacturer and retailer brands as one brand's innovative activities most likely has implications on the other; whether negative or positive.

\section{Research objectives}

The objectives of the study were:

- To identify aspects of manufacturer brand innovation that might inhibit and/or enhance retailer brands in grocery product categories.

- To assess how relevant aspects of manufacturer brand innovation that enhance retailer brands are for the determination of strategic management regimes that govern the coexistence of the two types of brands in the categories.

\section{Methodology}

Semi-structured interviews were carried out with managers in the New Zealand grocery retail and manufacturing sectors, and with consultants. The sampling method used was purposive (or judgemental) (Saunders et al., 1997), and the objective was to ensure that a variety of perspectives was captured from different types of interview participants deemed to be relevant to the research issues namely; grocery retail players, suppliers and industry experts. The sampling method is also in conformity with the advice of Patton (1990) regarding the pre-identification of the diversity of characteristics that would make up an appropriate sample and that would make it possible "to collect data to describe and explain the key themes that can be observed" (Saunders et al., 1997, p. 145). The interview participants consisted of grocery retail chain head office managers (three interviews with five managers - some jointly), ten supermarket managers from two major retail store brands of the retail chain, five managers and a director from the marketing/sales functions of grocery packaged goods manufacturing companies, a chief executive of a grocery packaged goods manufacturing company, and two consultants/executives conversant with the grocery retail and manufacturing sectors. In all, 22 interviews were held with respect to the objectives of this article as the research was actually part of a larger study. The research focused on five supermarket categories; milk, flour, cheese, breakfast cereals and tomato sauce, and manufacturer/supplier interview participants were systematically derived from all the categories in question.

Semi-structured interviews were chosen as the means of data collection because of their capacity to enable the interviewer to dig into the reasons for opinions, decisions or actions; and to probe answers in order to produce "a rich set of data" (Saunders et al., 1997, p. 215). Seventeen of the interviews were held face-to-face and five by telephone. An interview protocol was used to conduct the interviews and the interviews were tape-recorded for the later production of detailed research interview data. The research interview data/ transcripts were coded (Miles and Huberman, 1994) using a highlighter and key words in the margins, supported by numerals (and letters) to represent themes and sub-themes, and data supporting common themes were then grouped together and examined for meanings and patterns. In this regard, it should be noted that interview quotes that are presented in the results section of this paper under the themes identified are only representative, sample comments supporting each of the relevant themes derived from the analysed interview data. In addition, the quotes supporting the themes and subsequent conclusions are anonymously presented in respect of the anonymity guarantees given to interview participants and participating organisations. Also, job titles that were perceived to make the research participant or organisation easily identifiable were slightly modified.

\section{Results}

\subsection{The competitiveness of innovative manufacturer brands inhibits retailer brands}

Manufacturer brand innovation is perceived as posing a competitive threat to the retailer brand in the categories either by way of bringing about products that are superior and more appealing to consumers or by way of staying ahead of the retailer brand on innovative activities, or through intensifying innovative activities in order to reverse the gains of the retailer brand. Typical comments from the interviews include: "You can get innovations by proprietary brands that we don't have access to in private label, and then that can inhibit the growth of private label because people tend to head towards the innovation and what's new..." (Senior Manager, Retailer Brands); "There is more innovation from the manufacturer; from the branded product obviously, because non-branded is actually increasing in its share, and through its price especially in cheese and milk" (National Sales Manager, Manufacturing Company); With regard to the growth and share gains of the retailer brand, "I would say they would increase it [innovation] because the manufacturers are going to get their share back ... they might be innovative and come up with new products to combat the influx of private label" (Store Manager, Supermarket); "More private label penetration would see more innovation happening... trying to reverse the trend of private 
labels" (Managing Director, Manufacturing Company); Retailer brands are seen as trailing “... the supplier who has to constantly innovate to stay ahead of the private brand ..." (Director/Consultant). In these quotes, there is a common explicit or implied element of retailer brands being inhibited by the competitive activities of innovative manufacturer brands.

\subsection{Retailer brands are enhanced by manufacturer brand innovation driving category growth}

Manufacturer brand innovation is perceived as driving the growth of grocery retail categories and thereby benefiting not only the manufacturer brand but the retailer brand as well. In this regard, there is an element of the retailer brand being carried by the manufacturer brand. In addition, manufacturer brand category investment that benefits retailer brands is not limited to product/brand innovation, but extends to the marketing activities associated with the innovations as well. Representative comments include: "Manufacturer brands drive the category, bring innovation and generally drive promotion. So, it's not the role of store brands. Store brands are a follower" (Marketing Manager, Manufacturing Company).

If you leave that to private label, there is no funding for it; so you are not going to drive the category. Anybody who is going ahead in manufacturer categories, you are generally spending money on that product somewhere, whether it would be in advertising or innovation of new products or instore dealing ... They [manufacturers/manufacturer brands] are trying to grow their category as a whole, and by that, we [retailers/retailer brands] just get sucked along in the vacuum. (Store Manager, Supermarket)

Yeah, definitely; probably carrying the category and driving the category. It's certainly from a market research type point of view, but product development type ... as well as general market

research; generally in our category is very much driven solely by the brands [manufacturer brands], in my opinion. (Marketing Manager, Manufacturing Company)

But then it [manufacturer brand innovation] can also enhance private label because we can go into categories where there has been innovation and we can come along with private label and offer the same at a more competitive price... (Senior Manager, Retailer Brands)

It is acknowledged that manufacturing companies are:

... investing in the categories and new products because, if you look at Wattie's tomato sauce ... they spend on; if you go down and look at the sauces category now, you will see sauces that weren't there years and years ago ... Barbeque, Sweet and Sour; all the investments that these companies have been putting into the brands to expand the sauces range. And while it has diluted the sales of the standard tomato sauce, it's growing the category. (Store Manager, Supermarket)

The innovation ... and most of the TV advertising to bring customers into the store, is largely driven by manufacturer brands; and then when they get to the fixture, they have a choice of going private label or manufacturer brand. (Category Manager, Retail Chain)

In all these representative comments, there is a common element of retailer brands being enhanced by the innovative activities of manufacturer brands.

\subsection{The adaption of successful manufacturer brand innovations by retailer brands enhances retailer brands.}

Manufacturer brands lead on innovation and retailer brands largely follow by way of adapting/copying successful manufacturer brand/product innovations or through entering into categories that have been developed already by manufacturer brands. That way, the cost and risk of retailer brand 'innovations' is reduced. Furthermore, it is manufacturer brand resources such as labs, technology, specialised staff and knowledge that play a big part in bringing about the innovations, and in many cases adapting them or supplying them for retailer brand requirements should the retailer brand wish to introduce its own of the same nature. Sample comments include: "Most house brand products are copies of our mainstream branded products. There is a couple that aren't, but generally that's what they are, and it probably relies on the big brands to do the work" (Store Manager, Supermarket); "The house brands generally don't have innovation. They are normally followers of trends, and when a trend becomes successful, they tend to create a home brand [house brand] based on the success of that trend" (CEO, Manufacturing Company); "The market leaders [manufacturer brands] ... do the innovation. Private label follows" (Store Manager, Supermarket); "Bear in mind that private label is traditionally not innovative in that we don't enter into categories that are not already developed; so innovation for us comes down to looking for new product ideas mainly within existing categories” (Senior Manager, Retailer Brands). 
Innovation for us comes down to ... we identify new product opportunities ... We then go out to our suppliers and they use their resources, their labs, their technical people to come up with a proposal. Then they come back to us and they submit it, and we may have two or three suppliers who are doing that. And then we select the one that we want to work with. (Senior Manager, Retailer Brands)

Typically, what they [retailers] would do is approach a supplier to come up with formulation for them ... or they might get a favoured supplier to submit some samples and then say, okay, we want this made according to this recipe ... because they [suppliers] have the technology and the knowledge. (Director/Consultant)

Again in these sample comments, there is a common element of retailer brands being enhanced by the innovative activities of manufacturer brands.

\subsection{The customer pulling power of innovative manufacturer brands enhances retailer brands.}

The interest and customer pull generated in a category by leading and/or innovative manufacturer brands benefits both the manufacturer brand and retailer brand as retailer brands are displayed alongside manufacturer brands.

If you are innovating within products, there is generally a bit of money in new products, so you can make a bit of margin out of it, and it can bring you a bit of interest in a category which can be stagnant. (Store Manager, Supermarket)

"They [manufacturers] put the money/spend into it. As house brand, we ride off the back of it, hoping that the manufacturers drive people into the category and then they buy our house brand while they are there" (Grocery Manager, Supermarket); "It [manufacturer brand innovation and marketing] drives consumers to the category" (Senior Manager, Retail Chain); "The brands bring people to the store; private label doesn't do that" (Promotions Manager, Retail Chain).

As in 7.2 and 7.3, there is also a common element of retailer brands being enhanced by the innovative activities of manufacturer brands in the representative comments just given in this section.

7.5 Strategic management regimes that govern the coexistence of manufacturer brands and retailer brands in grocery retail categories are influenced by the ability of manufacturer brands to enhance retailer brands.

The contributions of manufacturer brands towards innovation and marketing in the categories is perceived to play a part in the determination of the level to which the retailer brand should grow and the balance between manufacturer and retailer brands in the categories. From a retail chain policy point of view, manufacturer brands form part and parcel of retailer brand marketing strategy because the retailer brand depends on the manufacturer brands. This is the prevailing perception and situation at least with regard to the grocery retail chain that forms part and parcel of the study for this paper. It is acknowledged however that such an approach to retailer strategic policy may not be standard among retail chains. The following are typical comments: "If private label becomes too big, then the proprietary brand will withdraw from marketing, innovation ... and that's where it all comes from because private labels aren't innovators" (Senior Manager, Retail Chain).

If private label is too dominant, you don't get the same degree of new product development and the onus then ends up on the retailer to develop the new products. And then you get the whole lot of cost structures coming into the business ... (Manager, Retail Chain)

If it [private label] becomes too dominant, then it slows down the growth of the category ... they [manufacturers] are going to spend money to make their product number one or they are going to spend money to invest in new technology or new products or something like that, which keeps the category alive; ... our house brand comes along behind and just gets dragged along, driven up by their spend at no cost to us. (Store Manager, Supermarket)

Some retailers may want to drive their private label share as high as possible and other retailers are saying ... 'we don't want to go all the way' ... because they have a different philosophy and different strategy, and may talk about leaving it to the supplier to bring innovation. And again, the innovation of the supplier flows through to private label unless you drive a business that is a pure private label business only... (National Sales Manager, Manufacturing Company)

In addition to influencing strategic retail policies in the area of balancing manufacturer and retailer brands as discussed above, related activities such as shelf space allocation, product display and category rationalisation 
also take into account brand strength and the customer pulling power of manufacturer brands resulting from innovation and marketing. As regards shelf space allocation/merchandising: -

Ultimately, we have a lot of power in terms of; we cannot range products if we choose not to. But, if they have strong brands, they have some power ... the power of the brand; so, we have to have them ... So, if you are talking about a company that comes from nowhere ... we are interested in it, but we are in the driver's seat and we can determine a lot ... (Store Manager, Supermarket)

Private label will always sit alongside its equivalent market leader in the fixture; and if the market leader is on the bottom shelf, then private label will be on the bottom shelf as well, so the consumer gets a true comparison of the products. (Senior Manager, Retail Chain)

And with regard to category rationalization: "If a brand is no longer adding value to a category and we have somebody else that can provide that value ..." (Category Manager, Retail Chain); "The market leaders don't lose too much share, but some of the smaller suppliers just drop off the bottom end." (Store Manager, Supermarket).

It would be fair then, to say that strategic management regimes that govern the coexistence of manufacturer brands and retailer brands in grocery retail categories are influenced by the ability of manufacturer brands to enhance retailer brands as the relevant comments given in the interviews in this section suggest either directly or indirectly that such aspects have a role in this regard.

\section{Discussion}

The results of this study have confirmed an aspect that is portrayed in the literature (Coriolis Research, 2002; Information Resources Inc., 2005; Kumar and Steenkamp, 2007; Verhoef et al., 2000); that of manufacturer brand innovation being employed as a competitive tool used by manufacturer brands against retailer brands, thus in a way inhibiting retailer brand progress (section 7.1). The results (sections 7.2 to 7.4) have however largely demonstrated the adequacy of the central argument advanced in this paper that manufacturer brand innovation does enhance retailer brands in grocery retail categories. The positive impact on retailer brands is on aspects related to driving category growth, copying of successful innovations, and customer pulling power; and the enhancement has relevance for the strategic management regimes governing the coexistence of manufacturer brands and retailer brands in the categories (section 7.5). By implication, from a managerial perspective, retail chain managers have to look at manufacturer brands as strategic resources that should be managed in a way that allows them to continue to benefit both retailer brands and manufacturer brands.

In addition, an aspect emphasised in the literature about the importance of innovation in driving growth and ensuring a strong market presence (e.g. BCG, 2005; Keller, 2003) has been confirmed by the results with respect to brand/product innovation and marketing driving grocery retail category growth. The research has further shaded light on the two opposing views (Conn, 2005) related to this aspect; one view being that manufacturer brands lead on innovation and the other being that retailer brands have become masters of their own destinies on innovation. The study has established that retailer brands are largely followers and dependent on manufacturer brands, at least within the New Zealand grocery retail industry, and with respect to the grocery retail chain that formed part of this study. However caution should be taken in making an assumption that the situation would be the same in other grocery retail environments. It would be reasonable to assume that in grocery retail environments such as the UK, where the retailer brand has almost reached maturity, the situation would be different.

The highly concentrated nature of the New Zealand grocery retail industry largely gives retail chains the balance of power in relation to manufacturers and their brands in business dealings; and in addition, with respect the five bases of power (French and Raven, 1959), retail ownership of supermarket shelves is a source of legitimate power that gives the retailers control of access to the shelves. Ownership of resources is a source of power (Mintzberg, 1983) in business and related relationships. Shelves are a resource that the retailers can use as reward power (through granting shelf space) or as punishment (through denial or reduction of shelf space). Furthermore, with regard to manufacturer brand ability to enhance retailer brands in the categories, manufacturer brands wield expert power due to their resources, skills and knowledge in the areas of brand/product innovation. Manufacturer brands also wield referent power due to the fact that retailer brands try to attain a close association with the leading manufacturer brands in shelf display and in the copying successful innovations by manufacturer brands. Manufacturer brand expert and referent power, as well as the power of ownership of innovation-related resources, which are all seen to enhance retailer brands, are taken into account in the determination of strategic policies on the coexistence of the two types of brands in supermarket categories. The study has therefore served to shed more light on the power-dependence relationship (Diamantopoulus, 1987; Emerson, 1962; Hickson et al., 
1971; Pfeffer, 1981) between manufacturer brands and retailer brands in grocery retail categories and how this impacts upon retailer brand strategy.

\section{Limitations and future lines of research}

The research was conducted in a limited number of supermarket categories within one retail chain and in one country. A larger number of categories would give a bigger representation of the supermarket situation, and the inclusion of other retail chains would also provide a better representation of the grocery retail sector as retail chains may differ in their policies. Additionally, extending the study to grocery retail industries in other countries would serve to create a better understanding of manufacturer brand/retailer brand coexistence under different industry environmental conditions. Also, it should be noted that the interconnection between manufacturer brand innovation and retailer brand innovation might be affected by the positioning policies of both brands as a number of authors have noted (e.g. Burt, 2000; Esbjerg et al., 2004) that in some countries retailer brands are marketed as real, innovative brands, while in others they just adopt a "me-too" approach.

\section{Conclusion}

The paper set out to establish key aspects of manufacturer brand innovation that inhibit and those that enhance retailer brands in grocery retail categories, and to assess the role played by these factors in the determination of strategic management regimes that govern the coexistence of manufacturer brands and retailer brands in the categories. The research employed a qualitative empirical study to demonstrate that manufacturer brand innovation does enhance retailer brands, and that the enhancement gets factored into retailer brand strategic policy. The theoretical value of this article is centred on offering a fresh perspective in explaining the coexistence of manufacturer brands and retailer brands in grocery retail categories, and the practical value lies in how certain bases of power can be employed to create value that influences retailer brand strategic coexistence with manufacturer brands.

\section{References}

Alegre, J., Chiva, R., \& Lapiedra, R. (2005). A literature-based innovation output analysis: Implications for innovation capacity. International Journal of Innovation Management, 9(4), 385-399.

Baden-Fuller, C. W. F. (1984). The changing market share of retail brands in the UK grocery trade 1960-1980. In C. W. F. Baden-Fuller (Eds.), The Economics of Distribution (pp. 513-526). Milan: Franco Angeli.

BCG. (2005). Innovation 2005. Boston, MA: The Boston Consulting Group, Inc.

Brenner, M. S. (1994). Tracking new products: A practitioner's guide. Research Technology Management, 37(6), 36-40.

Burt, S. (2000). The strategic role of retail brands in British grocery retailing. European Journal of Marketing, 34 (8), pp. 875-890.

Cartwright, D. (1965). Influence, leadership, control. In J. G. March (Eds.), Handbook of Organisations. Chicago: Rand McNally.

Chimhundu, R., \& Hamlin, R. P. (2007). Future of the brand management structure in FMCG. The Journal of Brand Management, 14(3), 232-239.

Conn, C. (2005). Innovation in private label branding. Design Management Review, 16(2), 55-62.

Coriolis Research. (2002). Responding to Private Label in New Zealand. Auckland: Coriolis Research.

Coriolis Research. (2005). An Overview of Private Label in Australia. Auckland: Coriolis Research.

Dapiran, G. P., \& Hogarth-Scott, S. (2003). Are co-operation and trust being confused with power? An analysis of food retailing in Australia and New Zealand. International Journal of Retail and Distribution Management, 31(5), 256-267.

Desrochers, D. M., Gundlach, G. T., \& Foer, A. A. (2003). Analysis of antitrust challenges to category captain arrangements. Journal of Public Policy \& Marketing, 22(2), 201-215.

Diamantopoulos, A. (1987). Vertical quasi-integration revisited: The role of power. Managerial \& Decision Economics, 8(3), 185-194.

Doyle, P., \& Bridgewater, S. (1998). Innovation in Marketing. Oxford: Butterworth-Heinemann.

Emerson, R. (1962). Power - dependence relations. American Sociological Review, 27(2), 31-41.

Esbjerg, L., Grunert, K. G., Bech-Larsen, T., Juhl, H. J., \& Brunso, K. (2004). Manufacturer and retailer brands 
in food retail assortments: Notes from a shopping trip across Europe. Working Paper Series, Paper No. 85, The Aarhus School of Business.

Freedman, P. M., Rayner, M., \& Tochlermann, T. (1997). European category management: Look before you leap. McKinsey Quarterly, 1.

French, J. R. P., \& Raven, B. (1959). The bases of social power. In D. Cartwright (Eds.), Studies in Social Power (pp. 150-167). Ann Arbor, MI: Institute of Social Research, The University of Michingan.

Hardaker, G. (1998). An integrated approach towards product innovation in international manufacturing organizations. European Journal of Innovation Management, 1(2), 67-73.

Hickson, D. J., Hinings, C. R, Less, C. A., Schneck, R. E., \& Pennings, J. M. (1971). A strategic contingencies theory of organisational power. Administrative Science Quarterly, 16, 216-229.

Hoch, S. J., \& Banerji, S. (1993). When do private labels succeed? Sloan Management Review, 34(4), 57-67.

Hunt, S. D., \& Nevin, V. R (1974). Power in a channel of distribution: Sources and consequences. Journal of Marketing Research, 11 (May), 86-193.

Information Resources, Inc. (2005). Private label: The battle for value-oriented shoppers intensifies. Times and Trends: A Snapshot of Trends Shaping the CPG Industry, November, 1-23.

Johne, A. (1999). Successful market innovation. European Journal of Innovation Management, 2(1), 6-11.

Joint Industry Project. (1995). Category Management Report. USA: Joint Industry Project on Efficient Consumer Response.

Keller, K. L. (2003). Strategic Brand Management: Building, Measuring, and Managing Brand Equity. (2 ${ }^{\text {nd }}$ ed.). Upper Saddle River, New Jersey, NJ: Prentice Hall.

Kracklauer, A. H., Mills, D. Q., \& Seifert, D. (2004). Collaborative customer relationship management (CCRM). In A. H. Kracklauer, D. Q. Mills \& D. Seifert (Eds.), Collaborative Customer Relationship Management (pp. 25-45). Boston, MA: Springer.

Kumar, N., \& Steenkamp, J. E. M. (2007). Brand versus brand. International Commerce Review, 7(1), 46-53.

Lindblom, A. (2001). Institutionalisation of category management in the manufacturer-retailer relationships. Proceedings of the ANZMAC Conference: Massey University, Palmerston North.

Miles, M. B., \& Huberman., A. M. (1994). Qualitative Data Analysis - An Expanded Sourcebook. Thousand Oaks, CA: Sage Publications.

Mintzberg, H. (1983). Power In and Around Organisations. Eaglewood Cliffs, NJ: Prentice-Hall.

Nielsen. (1992). Category Management: Positioning Your Organization to Win. Lincolnwood, Chicago: NTC Business Books.

Patton, M. Q. (1990). Qualitative Evaluation of Research Methods. (2 ${ }^{\text {nd }}$ ed.). Newbury Park, CA: Sage Publications.

Pfeffer, J. (1981). Power in Organisations. Marshfield: Pitman.

Rubio, N., \& Yague, M. J. (2008). Store brand management channel dependence: A model for the manufacturer's perspective. The Journal of Brand Management, 15(4), 272-290.

Saunders, M., Lewis, P., \& Thornhill, A. (1997). Research Methods for Business Students. London: Pitman Publishing.

Sethuraman, R. (2006). Private-label marketing strategies in packaged goods: Management beliefs and research insights. Working Paper Series: Marketing Science Institute, Report No. 06-108, 27-44.

Stern, L. W., \& El-Ansary, A. I. (1977). Marketing Channels. Eaglewood Cliffs, NJ: Prentice-Hall.

Sullivan, M., \& Adcock, D. (2002). Retail Marketing. London: Thomson.

Verhoef, P. C., Nijssen, E. J., \& Sloot, L. M. (2000). Strategic reactions of national brand manufacturers towards private labels: An empirical study in The Netherlands. European Journal of Marketing, 36(11/12), 1309-1326.

Weitz, B., \& Wang, Q. (2004). Vertical relationships in distribution channels: Marketing perspective. Antitrust Bulletin, 49(4), 859-876.

Wilkinson, I. F. (1979). Power and satisfaction in channels of distribution. Journal of Retailing, 55 (Summer), 79-94. 